\title{
CAN ENVIRONMENTAL HISTORY SAVE THE WORLD?
}

\author{
Sarah Brown \\ Steve Dovers \\ Jodi Frawley \\ Andrea Gaynor \\ Heather Goodall \\ Grace Karskens \\ Steve Mullins
}

\begin{abstract}
As a 'genre of history' in Australia environmental history is relatively new, emerging in the 1960s and 70s from encounters between history, geography and the natural sciences in the context of growing environmental concern and activism. Interdisciplinary in orientation, the field also exhibited an unusually high level of engagement with current environmental issues and organisations. In this era of national research priorities and debates about the role and purpose of university-based research, it therefore seemed fair to ask: 'can environmental history save the world?' In response, a panel of new and established researchers offer their perspectives on issues of relevance and utility within this diverse and dynamic genre. This article has been peer-reviewed.
\end{abstract}

\section{TANGLED ROOTS, SPREADING BRANCHES}

\author{
Andrea Gaynor \\ Dr. Andrea Gaynor is a member of the History Discipline Group in the School of Humanities \\ at the University of Western Australia. Her most recent publication is Harvest of the Suburbs: \\ An Environmental History of Growing Food in Australian Cities (UWA Press 2006).
}

Richard Grove (2001) has outlined a complex international and multidisciplinary genealogy for environmental history, stretching back to the late eighteenth century and pioneers of (western) conservation such as Alexander von Humboldt and George Perkins Marsh. However, environmental history as a more self-conscious - and perhaps exclusive - area of historical research and teaching emerged in the USA in the 1970s, when scholars such as Roderick Nash and John Opie began running courses in 'environmental history' and forming networks of historians interested in past human-environment relations. Some saw the 'new' sub-discipline as part of the more general expansion of the scope of history then underway: Nash, for example, placed it within the framework of New Left history, calling for attention to 'the biota and the land itself' when writing history 'from the bottom up' (Nash 1972: 363). Grove, however, suggests that the new 'environmental historians' were not blazing a trail, but 'arrogantly arrogating to themselves a term already being used by at least two other disciplines' (Grove 2001: 261).

In Australia, environmental history followed a somewhat different path, emerging as a fairly inclusive, if somewhat diffuse, enterprise: an inter-disciplinary area rather than principally a subdiscipline. The first works that have been placed (often retrospectively) under the broad umbrella of environmental history in Australia were by geographers and naturalists as well as a farmer, Eric Rolls. Historical heavyweight W.K. Hancock joined them in 1972 with his work on the plateau east of the Snowy Mountains, Discovering Monaro, in which he sought to trace the impact 
of people - as spoilers, restorers, and improvers - on the land. The opportunity to understand how people in the past had perceived and transformed the environment attracted students and a wider audience, and by the late 1990s environmental history in Australia was the subject of a handful of university courses and a substantial corpus of articles, books and theses.

Donald Worster has claimed that environmental history was 'born of a moral purpose, with strong political commitments behind it' (Worster 1989: 290). This was no less the case in Australia, where many of the early writers held in common a belief that Europeans in Australia had done a great deal of damage to the environment. They were interested in knowing how this had come about, at least partly in order to understand how such damage might be ameliorated or avoided in future. For some, knowing where we had gone wrong in the past seemed an important stepping stone towards a more environmentally-friendly future. Others seemed to have been content just to rescue the environment from 'the enormous condescension of history'.

Much environmental history in Australia has therefore had a vaguely instrumental orientation. In recent years demands on the government research funding pool have increased, and grants seem to be increasingly tied to meeting national strategic priorities, as well as the priorities of industry. Where has this left environmental history? Is it being lured into an unequal relationship with the sciences, as a kind of handmaiden, or is it an important and necessary complement? Can environmental historians successfully engage with the community, and should they aim to do so? If so, with which community? Is environmental history sufficiently reflexive to know what kind of difference it seeks to make? Or are attempts to impose or discern an overarching orientation among environmental historians stymied by the growing diversity within the field? And do environmental historians still believe we can help to save the world, and if so, what does that mean in the 21st century? As a panel of new and established researchers discussed these questions and more at the Australian Historical Association conference in Canberra in July 2006, a robust appraisal of environmental history's limitations, boundaries, assumptions and possibilities emerged, centred around the themes of engagement with science and scientists; negotiating hybrid urban landscapes; coming to terms with culturally-diverse approaches to the environment, locally and internationally; and the power of history as a mode of story-telling. Here, we offer a precis of those discussions.

\title{
CAN ENVIRONMENTAL HISTORY ENGAGE WITH POLICY?
}

\author{
Steve Dovers \\ Professor Stephen Dovers is with the Fenner School of Environment and Society, Australian \\ National University. His recent books include Environment and Sustainability Policy (Feder- \\ ation Press 2005) and Handbook of Disaster and Emergency Policies and Institutions \\ (Earthscan 2007).
}

This note asks what role might environmental history play in informing responses to one of the great challenges of our age - creating a more ecologically sustainable and humanly desirable future? This challenge needs an historical perspective, or rather a time depth, to be comprehended. My answer is therefore yes, environmental history can help 'save the world', but only if it can better engage with modern policy debates and negotiate its interactions with other knowledge systems. 
This evaluation comes from a peculiar perspective. My main focus is the policy and institutional dimensions of sustainability - not environment alone, but where environment, society and economy meet. ${ }^{1}$ I wandered into environmental history by accident. Trained in ecology but sensitized to history through work in heritage protection, I have had difficulty shaking off historical perspectives on modern problems. In the 1980s I undertook research in Monaro on future land use, but the history of use and perception of land proved pivotal (Dovers 1994a). Did this demonstrate the importance of history, or the system dynamics principle of path dependency? Whichever, the connection seemed absent in much environmental policy and management and prompted forays into bridging past and present in Australia's environment. ${ }^{2}$

Since then, I have balanced environmental history and policy, with the latter occupying the great bulk of my time. It has included collaborative endeavours, critiquing 'policy ad hocery and amnesia', worrying about the lack of purchase of history on policy and vice versa, increasing involvement in integrative research, and educational initiatives. ${ }^{3}$ Keeping a credible toe in environmental history has become non-viable and something has to give, so this is a farewell, with some sharp observations on its prospects as a participant in contemporary sustainability debates. ${ }^{4}$

Environmental historians, despite their unique ability to expose the human element in the environmental story, often speak more to a societal and policy agenda of 1960-70s environmentalism than to today's sustainable development agenda, which is no longer only about environmental protection and nature conservation. Instead, environmental history should connect with the broader sustainability debate. Sustainability is a higher-order social goal, akin to democracy, justice, the rule of law - a long term task of comprehension and institutional change (Connor and Dovers 2004). It is characterized by integration of environment, society and economy, by extended spatial and temporal scales, by thresholds and irreversible change, and by pervasive uncertainty, poorly assigned policy and property rights, and community engagement. Such problem attributes render it a different and difficult research and policy agenda (Dovers 1997), and baffle historians as much as others as they seek purchase on climate change, integrated land and water management, diffuse source pollution, ecosystem-based fisheries management, tradeenvironment links, and on the task of developing policy and institutional responses.

Issues of long-run sustainability have a deep past in classical economics, in the domain of renewable resource management and elsewhere, inviting historical explanation of an ever-enlarging agenda that struggles to gain purchase in policy. While the term is viewed by some as a recent and vague construct ('buzz word'), historians especially should understand and explain that is not the case. Those studying sustainability need to be aware of where the concept came from, and of diverse relevant work at the margins of many social and natural sciences and humanities, as well as in society and non-disciplinary knowledge systems. That is hard stuff and requires multiple, coordinated efforts. Environmental history is often not a team effort, due to lack of research funding, the single-author tradition of the humanities, and other reasons. That needs to change.

Environmental history also needs to be more inclusive. One of the great feats of recent disciplinary history has been to bring voices from the past that were previously held silent: women, minorities, Indigenous peoples. There are more voices now and I expect more in future. As Heather Goodall suggests below, environmental historians must let them speak, and hear what is said. 
There are also, however, issues of disciplinary inclusions and exclusions. In Australia, environmental history has been pioneered by non-historians: geographers, farmers, ecologists, foresters and so on. (Why?) Now that historians are becoming more engaged and infusing the field with their skills, some tend to claim the ground for themselves, defensive of their ownership and mastery of the past. In an often ahistorical world, where dominant disciplines and policy styles deny the past, and the humanities are besieged, this is understandable. Besides, people like scientists often do history badly. ${ }^{5}$ Yet historians are not the only people who can know and explain the past. With sustainability, others are essential in exposing cause, effect and context: biogeographers, lawyers, archaeologists, ecologists, economists.

Vignette one. In my work on Monaro (Dovers 1994a), it struck me that the masterful work of Sir Keith Hancock in Discovering Monaro (Hancock 1972), despite the excellent groundwork laid by Alec Costin two decades before in the equally masterful Ecosystems of the Monaro Region (Costin 1954), did not engage with environmental variation in the region, producing less than ideal analyses of human-natural system interactions. An historian saw this as 'a quibble over soil types'. Different geological provenances determine production potential, vulnerability to erosion, and vegetation alliances: these things matter, especially when misperceived, and indeed their importance was recognized, implicitly and explicitly, on Monaro from the 1840s onward. Historians see some things, but not others; scientists vice versa.

Historians have special skills in recognizing sources, interpreting documentary evidence, contextualizing, (de)constructing narratives, and should defend the quality of such contributions, but equally should recognise other skills. Paleoclimatologists are better at figuring the composition of the atmosphere a century ago; historians better at unravelling the societal drivers of industrial change. We need both, coordinated.

Complex human-natural system interactions defy single disciplines. I have difficulty envisaging environmental history as a sub-discipline, full stop, as its explanatory potential would be sacrificed to the constraints of sub-disciplinary boundaries around theory, method and scope. Yet there has been little discussion of the nature of interdisciplinarity in environmental history; that is a serious deficiency. Sustainability demands integrative approaches, and environmental history, as a notable interface between disciplines, owes itself and others reflection on the theory and practice of integration. ${ }^{6}$ It could itself learn from other 'interdisciplines' such as ecological economics and human ecology. The burgeoning literature on integration proposes many principles. One is that interdisciplinarity is defined by transformative potential. The engaged disciplines (and other knowledge systems in participatory research) are by definition open to exposure and questioning of underlying theory and methodological assumptions. Another principle is plurality of method. Historians rightly demand that scientists and economists recognise the validity of narrative and qualitative reasoning, yet can be dismissive of mathematisation, scientific rationality, systems modelling or cost-benefit analysis. Get over it. There are few theoretical or methodological approaches that are not somehow valid and useful regarding sustainability. We need detailed discussions of where and when, and in cross-referencing and connecting different approaches. 
There are sufficient examples of 'relevant' environmental history to indicate the potential of multiple approaches, whether implemented by historians or others. ${ }^{7}$

Environmental history tells fascinating stories of human engagement with the natural world, and I fervently hope that continues. But engagement with sustainability problems requires a supplementary set of activities.

Vignette two. During discussions of interdisciplinary initiatives in sustainability, an open-minded scientist made an aside - 'how can we get the humanities to take the next step'? The perspectives furnished by historians were fascinating, and probably relevant, but the connection was not there to enable use of the historical perspective in reshaping understanding and response.

If historians wish to contribute to contemporary debates (supplementary to their core activities), then they cannot simply point to distant connections between the past they describe and those questions, but must bring the two closer together. That does not mean abandoning the historian's art and scope, but taking the time and effort to engage with others (disciplines, governments, organisations) to frame mutually comprehensible questions.

One issue here is that from both a scientific and policy perspective, historians seem liable at times to confuse normative intent with a research topic. Is the 'environment' in environmental history really 'green'?

Vignette three. Environmental historians can confuse problem framing and analysis with normative intent. Scientists follow a particular rationality and epistemology. In an essay I had the pleasure of editing, Lance van Sittert takes Donald Worster to account for seeking 'not conversation, but conversion' when Worster instructed scientists to help defeat the 'world view of materialism' (van Sittert 2002).

Research related to the environment is often dismissed by disciplinary traditionalists as environmentalism. Often it is. Environment and sustainability are, alternatively, normative causes or contemporary policy agendas (Yes, that is a continuum.). As the latter they are stated in detail in countless policies and laws. To exercise scholarship in this domain does not require a normative position, as even official policy defines many unachieved aspirations and directions. Environmental historians should take these stated aspirations of society, and ask why have societies moved toward these goals (or not), and why might they in future (or not)? This requires a sound understanding of the difference between environmental issues, and policy problems and institutional challenges (Dovers 2005a: 41-50, n1).

Sustainability problems are defined by the long term, a casting forward to see the implications of patterns of production and consumption, settlement and governance. The corollary is that a long view backward is needed, too: the roots of these patterns are historically defined and pathdependent. Hence the need for historians, and others who can bring time depth, to explain better that past and connect it to current thinking and choices. This invites a different, supplementary style of environmental history that attends the issues above. It will engage with the nature of contemporary sustainability problems rather than selecting environmental issues of self-interest; it will be inclusive in its membership and in ownership and authority over the past; it will develop 
the art and craft of integrative scholarship; and it will connect, collaboratively, to policy problems. Such historical work does exist now, but more is needed.

\title{
THE HISTORICAL COASTLINES PROJECT, OR, WHAT DO SCIENTISTS REALLY WANT?
}

\author{
Steve Mullins \\ Associate Professor Steve Mullins is a member of the School of Arts \& Creative Enterprise, \\ Central Queensland University, Rockhampton Campus. His central area of research is \\ Maritime History, and he is the author of Torres Strait: A History of Colonial Occupation \\ and Culture Contact, 1864-1897 (CQUP 1995).
}

One measure of the relevance and utility of environmental history is the degree to which environmental management agencies incorporate it into their practice. Most of these are sciencedriven and science-led, so to a large extent the utilisation of history in their programs depends on what natural scientists think history might contribute. This brief discussion draws on the experience of historians who participated in Historical Coastlines, a five year project of the Cooperative Research Centre for Coastal Zone, Estuary and Waterway Management (Coastal CRC), established by the Commonwealth in 1999 to produce knowledge and decision-making tools for the effective, integrated environmental management of the coastal zone. It poses the question: when it comes to history, what do scientists really want?

From its beginning, the Coastal CRC was (it ceased in June 2006) determinedly committed to an integrated science philosophy. More than this, the first CEO, Roger Shaw, championed consilience, the idea popularised by the sociobiologist Edward O. Wilson that the best environmental solutions lay in the integration of the three fields of knowledge; science, social science and humanities (Wilson 1998). In keeping with this, the CRC funded a large and successful Citizen Science program, driven by environmental sociologists, which focused on investigating ways of improving community participation, understanding stakeholder needs, and building stakeholder capacity. It also funded a large-scale history project, Historical Coastlines.

There is now general recognition among environmental scientists that historical perspectives are useful, and in some circumstances essential, and this especially is true in specialisations where 'shifting baseline syndrome' is regarded as a significant problem. As the fisheries historian Poul Holm explains, in the past resource managers have tended to assume that the natural condition of an environment equals its first scientific description, even though systematic description by modern biology only began in the 1950s (Holm 2003). Holm echoes Jeremy Jackson's 1997 admonishment that ecologists 'need to turn to historical sources and rediscover the world' (Holm 2003: 208). In 2001 Jackson maintained, with respect to over-fishing, that 'retrospective data not only help to clarify underlying causes and rates of ecological change, but they also demonstrate achievable goals for restoration and management of coastal ecosystems that could not even be contemplated based on the limited perspective of recent observation alone' (Jackson et al. 2001: 629). Countering 'shifting baseline syndrome' is a powerful incentive for scientists to incorporate historical perspectives in environmental research, but 'retrospective data' is not necessarily history, and the scientific imperative to establish authentic baselines often blinkers scientists to history's other uses. ${ }^{8}$ Moreover, 'baselining' usually demands lower order research skills, and in many 
cases offers historians few satisfying intellectual challenges. Faced with this, and the prospect of being relegated to a handmaiden role, there is little incentive for historians to collaborate. Consequently, 'baselining', the thing that most environmental scientists know they need, is often left to non-historians.

At the July 2005 International Congress of Historical Sciences in Sydney, Verena Winiwarter made the point that for interaction between history and the natural sciences to succeed, each of what she called the 'coupled sub-systems' has to be given sufficient freedom to produce its best outcomes, including the generation of original approaches (Winiwarter 2005). This was the challenge Historical Coastlines researchers faced as the project evolved through negotiation over about a year in 2000-2001. What emerged, under the leadership of the historically-minded mangrove biologist Norm Duke, was a project organised in four research tasks: HC1 Community perspectives, HC2 Coastal features and natural habitats, HC3 Estuarine fisheries and fish communities and HC4 Vegetated tidal habitats, a model, which in the spirit of consilience, encouraged interaction and cross-fertilisation, while allowing the various specialisations to play to their strengths in pursuing historically informed explanations. In a pointer to what scientists also want from history, a task was added to the Historical Coastlines program: HC5 Communication products.

Historians led HC1, the Historical Coastlines (Community perspectives) task, with marine biologists, zoologists and remote sensing experts in the others. HC1 was originally conceived as a large-scale oral history project designed to feed data into other HC tasks, reflecting the tendency of environmental managers to think of history as a gateway to community. The Coastal CRC was committed to bridging the gap between science and community, and to the principle of participatory research. It instituted an elaborate system of community consultation, mostly through stakeholder meetings, and the initial feedback was that, where possible, community knowledge needed to be factored into research. While scientists are now mostly convinced that historical data sets are necessary to fully understand the workings of a natural system, community stakeholders insist that these be 'ground truthed' against current and traditional community knowledge. Indigenous stakeholders are the most insistent and influential advocates of this, but it is also the view among community stakeholders more generally. This understanding is at least in part a product of the pervasive tendency to privilege memory over history: an assumption that knowledge passed on from earlier generations is somehow more authentic and useful than the product of academic archival research. Thus, while the desire for community 'ground truthing' contributes to the perception that history is useful to environmental research, it also acts to confine historical research to what are often time-intensive and therefore expensive oral history projects.

Contributing to the push for a kind of history that involves extensive community engagement is the sensitivity within some environmental research organisations to the criticism that they are solely science driven, and neglectful of social and cultural issues and considerations. Oral history projects aimed strategically at selected stakeholder groups, or projects - say to copy, archive and make available historical photographs held in the community - are useful in ameliorating this perception.

This brings me to another use science has for history. Scientists are fixated on the idea that they are poor communicators. In HC1 we found this both a blessing and a curse; a curse because it came with the expectation that CRC historians would devote a disproportionate amount of 
time to what sometimes seemed to be CRC profile-raising exercises. On the positive side, it reminded us of narrative history's power to communicate, and alerted us to its potential to nourish the relationship between people and place. It is untrue that scientists are poor communicators; the Coastal CRC was led by charismatic and inspirational scientists, who knew how best to deploy the considerable communication resources at their disposal. Nor is science too dull or complex to have public appeal. But at its best narrative history is highly compelling, and it is difficult to match its capacity to capture the public imagination. In the beginning, communication tasks were a cross to bear, but as they became embedded in our practice we began enthusiastically to exploit history's capacity to reach people.

HC1 commenced with three objectives: to foster an awareness of the past states of local environments and of environmental change; to try to assess intergenerational attitudes to environmental change, what shaped them and how they shifted over time; and to encourage the view that effective environmental management is an intergenerational concern. In the CRC's second phase, HC1 focussed more on exploiting history's narrative power. Stephen Dovers, in setting out environmental history's practical uses, allowed that it also had 'a more innocent and less driven purpose... to unearth stories worth listening to' (Dovers 2000c: 17). But the power of stories should not be underestimated, especially those that relate to relationships between people and place. As Peter Hay reminds us, there is a powerful congruence between empathy with place and a commitment to the protection of local natural ecosystems. A deep sense of place instils a desire to act ethically towards that place (Hay 2002: 154). It is also formed out of emotional attachments to scenery; land and seascapes, built up, as Simon Schama puts it, 'as much from strata of memory as from layers of rock' (Schama 1995: 7). In 2001, as we wracked our brains about how we might deliver the measurable outcomes that scientists usually want, these kinds of ideas were far from our thoughts. But they shaped the project more as it matured. Experience led us to the view that while environmental history has many uses, one of its most valuable contributions to good environmental management is its capacity to nourish local relationships between people and place.

\title{
SAVING THE CITIES, SAVING THE WORLD
}

\author{
Grace Karskens \\ Dr Grace Karskens is a Senior Lecturer in the School of History and Philosophy in the Uni- \\ versity of New South Wales. Her publications include Inside the Rocks: The Archaeology of \\ a Neighbourhood (Hale \& Iremonger 1999) and The Rocks: Life in Early Sydney (Melbourne \\ University Press 1997).
}

If environmental history is to save the world, then environmental historians had better look to cities, where an increasing proportion of the world's population lives ${ }^{9}$. Cities are the greatest creations of humankind yet in a case of terrible hubris, they seem agents of their own vulnerability and destruction. There is now little or no doubt that climate change is happening, and cities are deeply implicated - both as major contributors to greenhouse gases, and as sites highly vulnerable to the impacts. These impacts include rising temperatures and heat islanding (which will make city centres unliveable and threaten food and water supplies), biodiversity loss, faster windspeeds and more frequent severe weather events. 
I want to argue for an approach which better integrates human history with studies of ecosystems and the biosphere in cities. To save the cities, or at least to try to make them more sustainable, environmental history needs to provide thorough accounts of how urban environmental problems and predicaments arise. But we also need to understand how, where and why nature exists in cities; to acknowledge urban people's relationship with their environments; and to recognise and document people's intimate connections with particular places in the cities. I'll come to why this is important at the end.

For some years now, environmental historians have acknowledged and argued that the nature/culture divide which posits humans outside (usually against) nature, is a false and misleading dichotomy. Hence, 'wilderness' is more a powerful cultural construct than objective fact. Conversely, its nemesis, the city, can be seen to some extent as an ecosystem, and as an assemblage of natural materials transformed. Richard White, discussing the 'cultural turn' in recent environmental history, argued forcefully that most landscapes must be seen as hybrid landscapes (White 2004b). They are the results of the historical interplay between nature and culture, rather than one or the other. Here White means 'culture' in the most general sense, as any aspect of the environment created, shaped or otherwise affected by humans. ${ }^{10}$

Cities are perhaps the ultimate examples of hybrid landscapes, yet, despite this pronounced 'cultural turn', urban environmental history still tends to focus on the deleterious environmental impacts of cities upon 'nature'. They take a utilitarian 'problems' approach, and with good reason. Driven in part by urgent current concerns, scholars are interested in identifying and tracking 'source and sink' patterns - that is, where cities have procured their energy and materials, how they transform natural resources, where they dump wastes after consumption and the environmental and social impacts of these processes. ${ }^{11}$ Often, though, the a priori assumption is that the role of humans, and the city itself, is unrelentingly destructive. Thus nature and the city remain opposed, cities are the villains, and the outlook is dire.

But urban environmental history clearly comprises both human and ecological experience: these are just as entangled in towns and cities as in rural and 'wilderness' areas, in the great dams and rivers. We know a lot about the messes that cities make, but until recently the cultural, emotional and visceral environmental experiences of city dwellers, and the extent to which nature exists in cities (particularly Australian cities) were rarely acknowledged or explored. ${ }^{12}$ It's also worth thinking more about the 'cultural turn': what kind of 'culture' are we talking about? While it can be argued that consumption and pollution are 'cultural', because they usually involve humans, I think a more specific definition of 'culture' would be useful here. As many non-urban environmental histories demonstrate, culture can be seen as 'webs of meaning', processes by which people make sense of their worlds, strands which bind together pre-existing ideas with ongoing encounters and learning, and which shape actions and responses. ${ }^{13}$

While economists and ecologists and even many social scientists routinely regard cultural beliefs, practices and behaviour as peripheral - a sort of 'icing on the cake' - in fact they are drivers. ${ }^{14}$ Some examples from urban history which are relevant to environmental history: how can we understand the complete turnaround in attitudes to Australian beaches in the nineteenth and twentieth centuries (from howling wastes to nature's invigorating paradise), and their physical transformations, without knowing about the history of beach culture? (White 2004a). Greenhouse gases from car exhausts and rampant freeway development might be properly related 
to the powerful culture and image of the car, and how owing and driving one makes people feel (Davison and Yelland 2004). Urban environments and environmental problems are so often made by millions of small individual actions, but those actions, too, are shaped by cultural ideas and habits which are historically formed. And historical perspectives could also provide useful reality check on scape-goating and easy clichés and buzz-words - like 'McMansions'. After all, McMansions are not new - it's just that they aren't all built by rich people now. Rich people's McMansions are heritage. In short, if cities are hybrid landscapes, if we are to study them as cultural as well as natural environments, then we need to use the methods, perspectives and insights of cultural history in tandem with those which deal with ecosystems and the biosphere. ${ }^{15} \mathrm{We}$ also need this get the message across to policy-makers, planners, public servants and ecologists.

How can such urban environmental histories be achieved? It's been done already. While a few pathbreaking earlier studies explored human environmental experience in cities and provide important insights into belonging, experience and sense of place, they generally did not engage with vital urban problems or urban ecologies. ${ }^{16}$ Not so still more recent works. Studies like Andrea Gaynor's Harvest of the Suburbs (Gaynor 2006) and Heather Goodall's work on the Georges River in Sydney (Goodall et al. 2004) demonstrate this new integrated approach - they move between and tie together social, cultural and ecological perspectives, seeing these aspects as part of the same past, which, after all, is what they were.

How, then, will urban environmental history save the world? First, by providing better, deeper, more fully-rounded analyses of the urban problems and phenomena now threatening the globe. Second, by reconnecting urban people with the outcomes of their actions. Cities, it seems, make us too comfortable; they insulate us from environmental outcomes. For example, the scientific story of climate change has not really been taken up in the public discourse, and so it is not taken seriously by the community or politicians. It is still seen as an obstruction, something that is not or should not be 'in my backyard'. We need environmental histories to link the scientific and public discourses. And third, by recognising the relationships between people and their environments, historians can track and tell the stories not only of the spoilers, but the environmental crusaders, the stories of tree-defenders and planters as well as tree-killers. They could thus dispel the widespread and false assumption that city people never have and never will be environmentally responsible, that they have no deep attachment to place. It is vitally important to tell such stories, to recognise such traditions and legacies, for in them lies hope. After all, in the end, it won't actually be historians saving the world, nor even planners, policy-makers or politicians alone, but people.

\title{
PAST PLANNING AND FUTURE PRACTICE: ENVIRONMENTAL HISTORY AND URBAN FUTURES
}

\author{
Sarah Brown \\ Sarah Brown is a post-graduate student in the History Discipline Group in the School of \\ Humanities at the University of Western Australia. The title of her PhD thesis is 'Greening \\ the Dream? An Environmental History of the Actors and Imaginaries Shaping the Suburbs \\ of Canberra and Perth 1946-1996'.
}


As Grace Karskens has suggested, there are multiple ways in which environmental historians can engage with urban environments. Here, I discuss the possibilities inherent within one approach, with a focus on the much-maligned suburbs ${ }^{17}$. Present urban planning efforts increasingly include attention to both environmental resources and environmental health. As with most things, however, environmental issues can be more fully understood when placed in their historical context (Kellogg 2002: 356). In identifying and accounting for the environmental, political and economic factors that have shaped human action to construct the built form, and tracing the extent to which individual understandings and visions of the environment have determined such action, environmental history can provide an information base for contemporary planning debates, as well as stimulating ideas for sustainable urban development in the future.

With approximately $70 \%$ of Australia's population living in suburban environments (ABS 2003), there is an obvious need to understand the long term desires and decisions that have led to such a pervasive pattern of urban settlement. My own research project, an environmental history of some of Australia's postwar suburban landscapes, seeks to do just that. Tracing the environmental imaginaries of those responsible for the suburban landscape, and the extent to which such imaginaries were, or in many cases were not, translated into the actual built environment, it provides an insight into the environmental values and ideals that have driven - and at times come into conflict with - the seemingly endless development of the suburban landscape, whilst also attempting to put contemporary planning problems into a wider perspective.

In a 1994 article on 'The Importance of an Urban Perspective in Environmental History', Christine Rosen and Joel Tarr sought to challenge Donald Worster's narrow definition of the field. ${ }^{18}$ According to Rosen and Tarr, rather than simply focusing on 'the role and place of nature in human life' as argued by Worster, environmental history should also 'examine nature's role and place in the history of urban life' (Rosen and Tarr 1994: 301). ${ }^{19}$ In attempting to demarcate the intellectual territory of urban environmental history, Rosen and Tarr outlined four dimensions of study: the effects of cities on the natural environment over time; the impact of the natural environment on cities; societal response to these impacts and efforts to alleviate environmental problems; and, the built environment and its role and place in human life as part of the physical context in which society evolves. Seeking to expand the field (as defined by Worster) so as to incorporate both the natural and the built environment, Rosen and Tarr argued that:

\begin{abstract}
rather than distracting attention from the history of society's transformation of the natural environment, the urban perspective contributes to the historical understanding of that transformation... The history of the built environment, the human-made environment, is intimately related to the history of the nonhuman world (306-307).
\end{abstract}

Working within this framework, environmental history can usefully examine the emergence and privileging of different viewpoints and agents involved in suburban development, and how they interact with the physical environment. ${ }^{20}$ We need detailed, comparative studies which encompass the landscape-centredness of environmental history, the diverse concerns of urban history, and the political interests and outcomes that are the focus of planning history; On this base we can produce studies of the historical interactions between changing environmental imaginaries and 
the shape of Australia's suburban landscape that usefully inform our present imaginings of future suburban development.

Take for example the Perth suburb of Kwinana. Located approximately 30 kilometres south of the City of Perth, Kwinana was established following the proclamation of the Oil Refinery Industry (Anglo-Iranian Oil Company Limited) Act (WA) in 1952. Under the terms of this Act, the State Government resumed about 7560 acres of land for the development of a new townsite, to enable the construction of housing for refinery employees. ${ }^{21}$ The multifaceted negotiations between those involved in the town's development (the Anglo-Iranian Oil Company, the Western Australian State Government, Margaret Feilman as consultant planner, and, to a lesser degree, the State Housing Commission), provide significant insights into diverse values, ideas and visions (or 'imaginaries') of suburban development, arising in different social and institutional contexts. If we also maintain a focus on the environment as it was transformed in the wake of these negotiations, we are able to discern a range of connections between the natural environment, human values and perceptions, and the built environment, building on the framework outlined by Rosen and Tarr.

Bearing in mind that the suburban landscape is produced through a complex, opaque system of collective (if unequal) decision-making that allows residents, planners, architects and builders, industry and government, to shape (in varying degrees) the landscape in their own manner, we need to not only understand the factors shaping diverse visions of the environment, but also to trace what happens to those visions in the process of building a new suburb. For example, in my study of Kwinana, whilst the Anglo-Iranian Oil Company set the parameters for the establishment of the town, the State Housing Commission and Margaret Feilman (who envisioned a suburban environment integrated into the Australian landscape) were largely responsible for the overall layout and the suburban skeleton of roads and subdivisions. ${ }^{22}$ Furthermore, landforms and prevailing wind patterns, ${ }^{23}$ as well as the developmentalist ideology of the postwar period, ${ }^{24}$ appear to have been crucial to the final siting and shape of the suburb.

This approach provides significant insights into the kinds of processes, negotiations and compromises involved in the creation of a suburb, and allows us to identify how those involved in suburban development have responded to or sought to reshape the environment. By examining, for example, how planning patterns determine land subdivision and street formation; how housing and domestic lifestyles shape suburban areas; the ways in which transport patterns influence housing development; and the extent to which residents, with their own understandings of the environment, imagine a suburban or residential area, environmental history can evaluate the extent to which suburban planning has, in the past, identified or ignored environmental considerations, and gain a greater understanding of the ways in which changing understandings of the environment have impacted on the planning and development of suburban landscapes. Furthermore, by grasping the historical context and roots of urban environmental concerns, we are able to more fully contextualise present discussions of issues such as urban consolidation.

As indicated, competing visions and different economic, political and environmental forces shape urban and suburban development. Kwinana's creation was influenced by a number of political decisions, economic demands, industrial ideology and environmental factors, interacting in contingent and complex ways. By bringing such issues to the fore, environmental history can be used to inform planners and other government organisations and residents about the various 
factors that structure a suburb's form and subsequent impact on the environment (Kellogg 2002). It is worth noting, however, that although environmental history is often used to mine the past for lessons or ways to avoid repeating history, this is not, nor should it be, its primary aim. According to Libby Robin and Daniel Connell, of much greater utility is the way in which environmental history can and should be used to make comparisons with the past, to highlight significant patterns in changing landscapes or political and institutional structures which are often taken as a given, thereby creating new discussions and suggesting new ways forward (Robin and Connell 2005: 21). In developing an appreciation of the processes that inform urban and suburban development - from the imaginary to the reality - we can make sense of urban pasts and develop greater insights into one of the many ways in which environmental history can be relevant to contemporary debates about urban futures.

\title{
WILL ENVIRONMENTAL HISTORY SAVE THE WORLD?
}

\author{
Heather Goodall \\ Heather Goodall is Professor of History at the University of Technology Sydney. Her recent \\ research focuses on gendered and racialised interactions through rivers in rural and urban \\ settings, discussed in, for example, her essays in her co-edited volume (with Hood-Washington \\ and Rosier) Echoes from the Poisoned Well: Global Memories of Environmental Injustice \\ (Lexington Press 2006).
}

Environmental history won't be saving the world unless it recognizes its continuing entrapment within western European cultural paradigms. Environmental history in Australia has taken up the early challenges of Raymond Williams (1973) in the UK and William Cronon (1995) and Richard White (1995) in the US that we should recognize the analyses buried in 'descriptions' of landscape. The contributors to Tom Griffiths and Libby Robin's widely circulating 1997 volume, Ecology and Empire raised questions about the ways in which colonizing settlers needed to see and depict landscapes in particular ways to valorise their own interventions (Griffiths and Robin 1997).This settler vision had often led to the erasure of the role of colonised peoples or to their depiction as essentialised and static 'noble environmentalists' (Head et al. 2005).

How far have we come since 1997? Indigenous voices are now being heard directly as Aboriginal writers and historians explain their cultural responsibility for country. ${ }^{25}$ None of them, however, would locate themselves in 'environmental history' nor see 'conservation' as their focal interest. Important works have emerged from a new generation of non-Aboriginal historians who do see themselves in this way. Looking for Blackfellas' Point by Mark McKenna (2002) and The Murray by Paul Sinclair (2001) are just two strong examples in which Aboriginal people are represented as continuing actors in changing post-invasion landscapes. Yet in many of these recent works, there remain echoes of 'noble environmentalists' and a nervous tension, which I share with great sympathy, about writing on Indigenous relationships with landscape and environment. Nor has environmental history in the United States responded more effectively. Peter Coates reviewed American environmental history in 2004 and wrote with some concern that despite a proliferation of subtypes, scholarly environmental histories continued to essentialise 'others', including African Americans as well as Native Americans, and paid no interest at all to the interaction between 'minorities' and 'nature' (Coates 2004: 414). 
If we look at environmental activist movements, the problem of persistent colonial vision seems even more pronounced, with a continued insistence on Aborigines fulfilling an imaginary 'noble environmentalist' role, and an Anglo Australian social base ${ }^{26}$ that appears reluctant to consider non-western cultural constructions of nature. In research into attitudes towards urban natural environments in the southwestern suburbs of Sydney around the Georges River, I am working with Anglo-Celtic, Aboriginal, Arabic speaking and Vietnamese Australians. There are distinct cultural differences between these groups in the most basic understanding of what is 'natural' and what the desirable role of human/nature relationships in religious and social life might be, and then in the way in which these ideas might engage in their new homes in suburban Sydney. ${ }^{27}$ But where, more generally, do we find analyses in the environmental history or activist literature of the views about nature and the environment held by Australians of Chinese background? Of Indian background? Both of these communities have histories of living in Australia as long as those of English settlers, sustaining distinctive cultures, but is there any inquiry into their understanding of 'nature', their views about the environment and of its history?

Even among the new writings in environmental history in Australia, we find very few which deal with other than Anglo-Celtic and Aboriginal cultures. It is as if, in environmental history as in so many other genres of history, these two groups were locked together in the Manichean dance of the settler colonial imagination, to the exclusion of others. Along with the research in Islamic countries on religion and nature, there are valuable studies of Middle Eastern cultures of nature from places like France with a high Muslim and Arabic recently-immigrant population. One by de Chatel specifically compares Christianity, Judaism, Islam and Mandaeanism and draws important conclusions about each religion's widely differing approaches to the relation between symbolism and practice in relation to water (de Chatel 2005). Where are such studies in Australia? If we don't even seek to inquire into the long established and sophisticated bodies of philosophy and the complex practices in relation to nature with which immigrant populations come to Australia, how can we begin to understand how they might have been perceiving and relating to the Australian environment which we assume they will interpret unquestioningly on our terms, as if it were the only way to 'see' nature.

But environmental historians in Australia need to go further than inquiring into the cultural diversity within their national borders in perceptions of the environment. We have remained confined to the cultural and environmental networks between settler colonies. Ecology and Empire (Griffiths and Robin 1997) was innovative precisely because it opened up this path, and later work has followed this path fruitfully. However Australian historians have been reluctant and, again, nervous, about plunging into the extensive literatures of developing countries who have in fact shared in colonial experiences but do not have substantial bodies of European 'settler colonials' to continue to reflect on their desires for or their critiques of 'pristine wilderness'.

One accessible example is that of recent Indian debate. In India, it is historians who have led the emerging, sophisticated engagement of environmentalism which involves a critique as well of western environmental history. We should be reading these debates not only because they are at times so different from our own, but also because they are often so directly comparable to the questions we in Australia are asking of environmental history and of environmental politics.

An early contributor to the Indian critique was Ramachandra Guha, whose volume Environmentalism: a global history (Guha 2000) summarized his previous interventions. He draws on 
a much wider range of origins for environmental consciousness than is usual in western writing, which is itself an important reason to engage with his work. One of his central arguments has been that the west developed an environmentalism of the rich, divorced from productivist relations with the environment and reflecting the interests of elites. An alternative is the environmentalism he investigates in developing countries, an environmentalism of the poor, generated from direct involvement with productive processes like agriculture or harvesting. His analysis can be interrogated: it could be countered that the environmentalism of the rich, at least here in Australia, has arisen directly from the productivist processes of appropriation of colonized land and labour. A recent Indian critique is that of Amita Baviskar, who shows how the environmentalism of the poor in fact mobilises power because it articulates with the western and elite Indian urban ideas and agencies (Baviskar 2004). Yet Ramachandra Guha's approach cannot be dismissed, as Aboriginal and indeed, working class white Australians might affirm. It continues to be the case that western environmental agencies exert significant power on the world stage. While in some situations this seems to be futile, in others it can change outcomes on the ground significantly. Mobilisations of western environmentalists for example led to the World Bank deciding it would not fund the expansion of the Sardar Sarovar Dam on the Narmada river. But such mobilized power, if it draws on a dubious sense of history, can also identify some local groups under environmental assault as 'indigenous' and therefore as 'noble environmentalists', worthy of being supported. Environmental scholars like Baviskar and others have documented cases in which some players in the complex situations of tropical developing countries have been not identified by environmental movements as 'indigenous' and consequently have been denied support. These cases reflect the failure to recognise the complex histories of such situations in many developing nations (where claims to be 'indigenous' are often problematic, variable and contested) and lead to the imposition of simple settler-colonial models of 'wilderness' onto developing country populations. It is seen by locals as no accident that such the external dispensation of politically charged labels like 'environmentalist' or 'indigenous' often works in the interests of international tourism and transnational miners.

Since the days of Ramachandra Guha's early interventions, there has emerged a rich and diverse corpus of environmental history written and published in India. It is as yet little known in Australia but it is striking for its resonances with Australian concerns and questions. Just in the area of my direct interest, the intersection of ethnicity, indigeneity and the environment, there are important examples such as Environment and Ethnicity on the forests of Maharastra, by Sumit Guha (1999); In the Belly of the River on the Narmada by Amita Baviskar (1995); while recent edited volumes like Battles Over Nature (Saberwal and Rangarajan 2003) and Ecological Nationalisms (Cederlof and Sivaramakrishnan 2005) give a taste of new and cutting edge work in the field. ${ }^{28}$ Many of these analyses argue that western environmental thought, historically and in the present, has arisen from the processes of colonialism. They argue that colonialism imposed static classificatory systems on both lands and peoples as the imperial power struggled to assert control, extract profits or retain power. These classifications have continued to shape interactions in more recent periods as western observers have sought recognisable subjects of analysis. It is clear that there are strong parallels with historical conditions and questions in Australia, despite both the many real differences and the rarity of the comparison being drawn at all. 
Environmental historians in Australia are restoring our sense of complexity and change, as well as our recognition of interaction and uncertainty in post-invasion environmental history in Australia. Sumit Guha and others would argue that they should go much further. One of the implications of the Indian work is that we can think outside the boundaries of western paradigms of nature. Another is that the effects of colonialism on our understanding of pre-invasion as well as post-invasion ecologies - and politics - can be interrogated far more deeply than has been done so far. Sumit Guha closes his 1999 Environment and Ethnicity with the sentence: 'the major object of this work has been to banish social and ecological stasis from the woodlands of the world and to propose the reinstatement of the contingent, the political and the historical therein' (Guha 1999: 201).

This possibility will be more available to us if we can open up the cultural constraints of western philosophies and colonial legacies. And in this, environmental history may be able to give back something valuable to environmental politics, which will need all the cultural insights it can gather if it is indeed to change the world.

\title{
ENVIRONMENTALISM TO TRANSNATIONALISM
}

\author{
Jodi Frawley \\ Jodi Frawley is a postgraduate student in the Department of Gender Studies, University of \\ Sydney. Her PhD thesis topic is 'Networked Transnationalism: Sydney Botanic Gardens \\ 1890s-1920s'.
}

When I was a little girl, my family moved from Blackall in Central Queensland to Noosa on the Sunshine Coast. At that time Noosa was still a fishing village with the very rudimentary beginnings of a tourist industry. My father was a recreational fisherman and for him the fishing landscapes gave him a kind of connection to the same places that Margaret Somerville (2004) tries to capture in her book Wildflowering. With Grant's Guide to Fishes (Grant 1965) tucked under his arm and charts and weather maps ever ready, he embarked on a quest to read his way into these places. As the local doctor, he also offered up his medical expertise in exchange for stories of river and sea from his patients. As he moved into the landscape he learnt how to read the sandbars, map the tidal patterns, even to think like a fish! By living Noosa, its estuaries, lakes and beaches, this environment became my father's passion. He walked a similar line to that explored by Eric Rolls in A Million Wild Acres (Rolls 1981) which Libby Robin and Tom Griffiths capture as a 'joint advocacy' between human settlement and conservation principles (Robin and Griffiths 2004: 447). His environmental sensibility wavered between his desire to fish and enjoy these places, and to protect habitats for their own value.

This passion led him into the sort of grassroots environmental activism that kept sand mining off Sunshine Beach and saw the Cooloola National Park first gazetted in the mid 1970s. My mother, who journeyed, fished and advocated with him, turned from that voluntary involvement to become Noosa Shire's first female councillor in 1974. Her election campaign was built on a platform of four C's - conservation, culture, controlled development and consolidation of existing areas. This is probably why the local journalist described her as controversial, clever, cantankerous, capable and contrary. ${ }^{29}$ They were not ecologists, botanists or farmers and were definitely not 
historians, but they were part of a broader milieu of environmental awareness of the 1970s that also influenced the early work of Eric Rolls and Keith Hancock.

It was hardly a surprise really that I ended up working in the Heritage area in Queensland, a particularly direct engagement between history and current concerns. One of the guiding principles for me in that kind of work was that place is the prism through which we both read and tell our stories. Heritage work is interdisciplinary, combining and applying the various knowledges and practices of architecture, archeology, law, public administration and - central to any heritage process - the needs of the custodians of the site under question. The role of the historian in this work is really to story-tell place; that is, to identify what makes a place's story important to the communities in which we all live so that informed decisions can be made about things like fabric, development and site management. In that work, the relevance of environmental history hinges on our capacity as storytellers to relay the human-ness of place and translate those stories into useful and practical assessment and advice.

What has often emerged from such work is a series of limitations that constrain this storytelling. Environmental history that follows from activism has very often been raced, classed, gendered and nationalized. In Queensland, for example, the state heritage register entry number 601273 is the Cactoblastis Memorial Hall at Boonarga. It is a small community hall in a tiny rural town near Chinchilla, in central Queensland. The hall memorializes, according to the assessment, an 'economic and scientific event'. The entry picks up history at the moment when biological control, in the form of the cactoblastis moth, was introduced to Queensland to overnight eradicate prickly pear which had made the land 'useless for production, ${ }^{30}$ an event Ian Tyrrell refers to as 'blasting the cactus'(Tyrell 1999). This event and its memorialisation reiterate a history that reifies the white male scientist and celebrates human control over unruly Australian land. Such useful histories have a lopsided effect; they disavow the myriad of other stories that gather around the prickly pear, and willfully forget the nature-cultures of Australian settler history.

So in a way, the research that I am doing now actively disengages with the type of utility that heritage work embraces. My thesis seeks ways to get beyond these sorts of limitations and to experiment with a different methodology in the telling of stories. It is a perspective that sets aside some of those boundaries - like the nation, like empire, and in some cases humans themselves. This environmental history approaches the subject differently, by instead choosing to look at the relations between objects and humans as they operated transnationally.

I am using actant network theory as a way to understand the transnationalism of the Botanic Gardens in Sydney. This involves a flattening out of the field of study such that 'the important questions' according to Susan Liegh Star and James Griesemer, 'concern the flow of object and concepts through the network of participating allies and social worlds' (Star and Griesemer 1989: 389). Such actant networks distribute agency across collectives of humans and non-humans, allowing the relationships between them and the action they stimulate to come clearly into view (Law 1991: 7-8). The Sydney institution, like colonial botanic gardens all over the world, engaged in the movement of plants, people, technologies, machines and knowledge in sophisticated communication systems that operated with pathways both inbound and outbound from its location at Farm Cove. In order to interrogate such movement, I am considering a series of plants to discover what a network might constitute and what effects global knowledges might have in local places. 
Is it possible then to consider the history of the prickly pear beyond the moment of the triumph of applied science? (For example see Dodd 1940; Freeman 1992; Johnston and Lloyd 1982; Lines 1991; Rolls 1984). If we look at this history as an actant network that does not privilege the human then it is indeed very complex. In fact, the introduction of prickly pear was extraordinarily successful. It not only adapted to its new landscape, it was welcomed in an indigenous floral community, the brigalow-belah forests (Bailey 1984; Dick 1960), and it responded to the climatic conditions of local regions (Harvey-Johnston 1924). Wildlife of all sorts, but particularly birds, quickly incorporated it into their diets (Froggatt 1912; Payne 1925). Cattle, flood, and the plant's own capacity for multiple means of reproduction saw the plant move into 60 million acres of Australian land by 1924.

As the new hybrid landscape grew in area and size it became known as prickly pear land and it literally blocked the human settlement of these regions. Although this perspective shows its success, 'successful' was never a way that the prickly pear land was articulated. Instead the action of the plant, in establishing a new hybrid landscape, dictated the behaviour of Australians. Prickly pear prohibited the settlement of Australians at a time when settling was a national imperative. In response, humans sought to displace the prickly pear in this collective, by mobilising knowledges, machines and biologies from places and people all over the world, not just biological control. The network was never static, but always undergoing change subject to flow and action, and stretched to Europe, India, South Africa and North and South America. All the while the Sydney Botanic Gardens made up one part in this shifting network connected to prickly pear land in northern New South Wales and southern and central Queensland. ${ }^{31}$

This is not research that is directed at solving a particular environmental problem, but it may provide useful insights in a more general way. It might have the kind of utility that helps us to understand the complex processes by which present environments have come into existence. It should also help us to see that if we are to embrace the idea of change, process and hybridity in our landscapes then we must also challenge concepts that tend to constrain and simplify our environmental histories. Some of the work that comes out of environmental history should grapple with stories, ideas, and philosophies that are not directly linked to current trends, themes or policies. This genre of history should also support research projects that are less easy to categorise, but hopefully just as important to our understanding of the transnational networks of humans and non-humans in Australian landscapes.

\section{ENDNOTES}

For a 'position statement', see Dovers (2005a).

Albeit one that took a decade see, Dovers (1994a); Dovers (1994b).

Principally the 3rd year course 'Readings in environmental history' in the College of Science at the ANU, which I developed and convened for 7 years until 2005, in later years with Libby Robin.

The past two decades have involved contact with disciplines including history, law, geography, political science, economics, a range of natural sciences, and government and civil society. The following is focused on environmental history. Often sharper comments could be made concerning those others.

I could give examples, but diplomatically will not.

See Barnett et al. (2003: 53-76); Dovers (2005b;Dovers 2000a).

See various contributions in Dovers (2000b). 
For these see Dovers (2000b).

This paper shares some material with Karskens 2006.

See also Cronon (1996) and Worster (1994: 14).

For discussion see Brosnan (2004, p. 116); Hurley (1995); Tarr (1996); and Melosi (2000; Melosi 2001). For survey discussions of the literature, see Coates (2004); MacNeill (2003, pp.6-7); and Keyes (2000: 380-90). For surveys of European urban environmental history, with its focus on materials and energy exchange, see Winiwarter et al, (2004: 501-30, especially 511, 512, 514, 515, 530); and Bruggemeier (2000).

But see Price (2006).

See Geertz (1975, 6ff); Williams (1984, p.90). Historic-cultural readings/analyses of cities such as Barth (1980) and Rosenzweig (1985) offer suggestive ways to begin to read city environments in cultural ways.

See for example Goodland (1995). Here 'environment' and 'economy' are the substructure upon which the 'social' rests.

Alberti recognises that 'the quality of urban environments depends on physical elements and socioeconomic conditions as well as on the culture and values of urban communities' but also that no means exist as yet to incorporate such values into models for measuring urban sustainability, and so does not attempt to do so. Alberti (1996: 388, 389, 390) [my emphasis].

See Modjeska (1989) and Read (1996); Read (2000). There are also some more specialised works in park and garden history, bushwalking and the rise of environmentalism.

This paper shares some material with Brown 2007.

See Worster (1990: 1089).

Rosen and Tarr are not the only ones who have sought to challenge Worster's definition. See also Melosi (1993) and Hays (1993).

See for example Rome (1994); Rome (2001). In the Australian context Tony Dingle also provides a useful case study (Dingle 1993).

For further information on the planning and development of Kwinana, see Feilman (1955), Russel (1979) and Melotte (1997).

Margaret Feilman and the State Housing Commission operated under the jurisdiction of the Town Planning Board.

One of the primary determinants for the town's final location was that it be located somewhere free of possible fumes and pollutants from the new refinery. Feilman has suggested that 'after an investigation of prevailing winds at different times of the year it was clear that we needed to be... south [of the refinery] so as not to experience [such] problems'. Feilman, M. Interviewed by Moran, R. Battye Library of Western Australian History. Perth; OH 2402/1-24 (1). 1991.

Lenore Layman provides a detailed discussion of industrialisation and the postwar ideology of development within Western Australia. (Layman 1982).

See for example Birch (2001) Birch (2004) and Huggins et al. (1995).

See for example Davison (2005a); Davison (2005b).

See Goodall et al. (2004).

Other important recent monographs include, Sundar (1997) and Prasad (2003)

'Noosa's Leading Ladies: Controversial Councillor,' The Noosa District News, June 12 1975, p.2. 
Cultural Heritage Branch, 'Cactoblastis Memorial Hall,' in Queensland Heritage Register (Brisbane: Queensland Environmental Protection Agency, c1997).

A full elaboration of this argument appears as Frawley 2007.

\section{REFERENCES}

Australian Bureau of Statistics. 2003. Australian Social Trends. Cat. No. 4102.0. Canberra: Australian Bureau of Statistics.

Alberti, M. 1996. 'Measuring urban sustainability'. Environmental Impact Assessment Review 16: 381-424.

Bailey, A., editor. 1984. The Brigalow Belt of Australia. Brisbane: Royal Society of Queensland.

Barnett, J.; Ellemor, H.; Dovers, S. 2003. 'Interdisciplinarity and sustainability'. In New Dimensions in Ecological Economics: Integrated Approaches to People and Nature, edited by Dovers, S.; Stern, D.; Young, M. Cheltenham: Edward Elgar: 53-76.

Barth, Y. 1980. City People: The Rise of Modern City Culture in Nineteenth Century America. New York: Oxford University Press.

Baviskar, A. 1995. In the Belly of the River: Tribal Conflicts over Development in the Narmada Valley. New Delhi: Oxford University Press.

Baviskar, A. 2004. 'Red in tooth and claw? Looking for class in struggles over nature'. In Social Movements in India: Poverty, Power and Politics, edited by Ray, R.; Katzenstein, M. F. Lanham: Rowman and Littlefield: 161-178.

Birch, T. 2001. 'Returning to country'. In A Museum for the People: A History of Museum Victoria and its Predecessors, 1854-2000, edited by Rasmussen, C. Melbourne: Scribe Publications: 396-400.

Birch, T. 2004. "“These children have been born in an abyss”: Slum photography in a Melbourne suburb'. Australian Historical Studies 35 (123) (April): 1-15.

Brosnan, K. 2004. 'Effluence, affluence and the maturing of urban environmental history'. Journal of Urban History 31 (1): 115-123.

Brown, S. 2007. 'Surveying our past and building our future: An environmental history of an Australian suburb'. Limina: A Journal of Historical and Cultural Studies 13: 23-33. Available from: http://www.limina.arts.uwa.edu.au/_data/page/59120/Brown.pdf.

Bruggemeier, F. 2000. 'New developments in environmental history'. Proceedings of the 19th International Congress on Historical Sciences. Oslo, August 2000.

Cederlof, G.; Sivaramakrishnan, K., editors. 2005. Ecological Nationalisms: Nature, Livelihoods and Identities in South Asia, Nature Culture, Conservation. Delhi: Permanent Black.

Coates, P. 2004. 'Emerging from the wilderness (or, from redwoods to bananas): Recent environmental history in the United States and the rest of the Americas'. Environment and History. 10 (4): 407-438.

Connor, R.; Dovers, S. 2004. Institutional Change for Sustainable Development. Cheltenham: Edward Elgar. Costin, A. 1954. A Study of the Ecosystems of the Monaro Region of NSW. Sydney: Government Printer.

Cronon, W., editor. 1996. Uncommon Ground: Rethinking the Human Place in Nature. New York: W. W. Norton \& Co.

Cronon, W., editor. 1995. Uncommon Ground: Toward Reinventing Nature. New York: Norton.

Davison, A. 2005a. 'Australian suburban imaginaries of nature: Towards a prospective history'. Australian Humanities Review. 37 (December). Available from: http://www.lib.latrobe.edu.au/AHR/archive/Issue-December-2005/davison.html.

Davison, A. 2005b. 'Urban nature and Australian environmentalism: The urban experience of members of environmental groups in Hobart and Perth'. State of Australian Cities National Conference. Available at: http://www.griffith.edu.au/conference/soac2005/published_papers/environmental_city/env08a.pdf.

Davison, G.; Yelland, S. 2004. Car Wars: How the Car Won Our Hearts and Conquered Our Cities. Sydney: Allen and Unwin. 
de Chatel, F. 2005. 'The Hammam and the Mikvah: Physical and ritual purity in Islam and Judaism [Abstract Only]'. Paper presented at the Water and Civilization symposium, Paris, France, 1-4 December. Publication forthcoming.

Dick, R. S. 1960. 'Five towns of the Brigalow country of South-Eastern Queensland Goondiwindi-Miles-Tara-Taroom-Wondoan'. Department of Geography Papers University of Queensland 1 (1): 3-35.

Dingle, T. 1993. 'Who has shaped "bald brick-veneerdom"?' In Created Landscapes: Historians and the Environment, edited by Garden, D. Carlton: The History Institute: 17-27.

Dodd, Alan. 1940. The Biological Campaign against Prickly-Pear. Brisbane: Commonwealth Prickly Pear Board.

Dovers, S. 2005a. Environment and Sustainability Policy: Creation, Implementation, Evaluation. Sydney: Federation Press.

Dovers, S. 2005b. 'Clarifying the imperative of integration research for sustainable environmental management'. Journal of Research Practice 1 (2), article M1: 1-19. Available from: http://jrp.icaap.org/index.php/jrp/article/view/11/30.

Dovers, S. 2000a. 'On the contribution of environmental history to current debate and policy'. Environment and History 6 (2): 131-150.

Dovers, S., editor. 2000b. Environmental History and Policy: Still Settling Australia. Melbourne: Oxford University Press.

Dovers, S. 2000c. 'Still settling Australia: Environment, history and policy'. In Environmental History and Policy: Still Settling Australia, edited by Dovers, S. South Melbourne: Oxford University Press: 2-23.

Dovers, S. 1997. 'Sustainability: Demands on policy'. Journal of Public Policy 16: 303-318.

Dovers, S. 1994a. 'Still discovering Monaro: Perceptions of landscape'. In Australian Environmental History: Essays and Cases, edited by Dovers, S. Melbourne: Oxford University Press: 119-140.

Dovers, S. 1994b. 'Sustainability and 'pragmatic' environmental history: A note from Australia'. Environmental History Review 18 (3): 21-36.

Dovers S.; River, S.W., editors. 2003. Managing Australia’s Environment. Sydney: Federation Press.

Feilman, M. 1955. 'Kwinana New Town'. Town and Country Planning: 381-385.

Freeman, Donald B. 1992. 'Prickly pear menace in Australia 1880-1940'. The Geographical Review 82 (45): 413-428.

Frawley, J. 2007. 'Prickly pear land: Transnational networks in settler Australia'. Australian Historical Studies 130: 323-338.

Froggatt, Walter W. 1912. 'Birds and prickly pear'. Agricultural Gazette of New South Wales 23: 943-944.

Gaynor, A. 2006. Harvest of the Suburbs: An Environmental History of Growing Food in Australian Cities. Crawley: University of Western Australia Press.

Geertz, C. 1975. 'Thick description: Towards an interpretative theory of culture'. In The Interpretation of Cultures, edited by Geertz, C. London: Hutchinson.

Goodall, H.; Wearing, S.; Byrne, D.; Kijas, J. 2004. 'Recognising cultural diversity: The Georges River project in south-western Sydney'. In Sustainability and Social Science Round Table Proceedings, edited by Cheney, H.; Katz, E.; Solomon, F. Sydney: Institute for Sustainable Futures and Melbourne: CSIRO Minerals. Available from: http://www.minerals.csiro.au/sd/pubs/.

Goodland, R. 1995. 'The concept of environmental sustainability'. Annual Review of Ecology and Systematics 26: $1-24$.

Grant, Ernie. 1965. Guide to Fishes. Brisbane: Department of Harbours and Marine, Queensland.

Griffiths, T; Robin, L., editors. 1997. Ecology and Empire: Environmental History of Settler Societies. Edinburgh: Keele University Press.

Grove, R. 2001. 'Environmental history'. In New Perspectives on Historical Writing, edited by Burke, P.

2nd ed. Cambridge: Polity Press: 261-282.

Guha, S. 1999. Environment and Ethnicity in India. Cambridge: Cambridge University Press.

Guha, R. 2000. Environmentalism: A Global History. Oxford: Oxford University Press. 
Hancock, K. 1972. Discovering Monaro: A Study of Man's Impact on His Environment. Cambridge: Cambridge University Press.

Harvey-Johnston, T. 1924. 'The relation of climate to the spread of Prickly Pear'. Transactions and Proceedings of the Royal Society of South Australia: 269-296.

Hay, P. 2002. Main Currents in Western Environmental Thought. Sydney: UNSW Press.

Hays, S. 1993. 'From the history of the city to the history of the urbanized society'. Journal of Urban History 19 (August): 3-25.

Head, L.; Trigger, D.; Mulcock, J. 2005. 'Culture as concept and influence in environmental research and management'. Conservation and Society. 3 (2): 251-264.

Holm, P. 2003. 'History of marine animal populations: A global research program of the Census of marine life', Oceanologica Acta. 25: 207-211.

Huggins, J.; Huggins, R.; Jacobs, J. 1995. 'Kooramindanjie: Place and the postcolonial'. History Workshop Journal. 39 (Spring): 165-181.

Hurley, A. 1995. Environmental Inequalities: Class, Race and Industrial Pollution in Gary Indiana, 1945-1995. Chapel Hill: University of North Carolina Press.

Jackson, J.; Kirby, M.; Berger, W.; et al . 2001. 'Historical overfishing and the recent collapse of Coastal Ecosystems'. Ecology 293 (5530): 629-637.

Johnston, W.; Lloyd, P. 1982. 'The fight against cacti pests in Queensland'. Queensland Agricultural Journal 108 (4): 215-21.

Karskens, G. 2007. 'Water dreams, earthen histories: Exploring urban environmental history at the Penrith Lakes Scheme and Castlereagh, Sydney'. Environment and History 13 (2): 115-154.

Karskens, G. 2006. 'Urban people, urban places, urban resilience: A paper in honour of Patrick Troy'. Vulnerability on Australian Cities: Towards Sustainability and Security: a Public Symposium, May 2006: Available from: http://www.griffith.edu.au/centre/urp/MiscDocs/GraceKarskensFinalPaper.pdf.

Kellogg, W. 2002. 'Nature's neighbourhood: Urban environmental history and neighbourhood planning'. Journal of the American Planning Association. 68 (4): 356-370.

Keyes, J. 2000. 'A place of its own: Urban environmental history'. Journal of Urban History 26 (3): 380-390.

Law, J. 1991. 'Introduction: monsters, machines and sociotechnical relations.' In: A Sociology of Monsters: Essays on Power, Technology, and Domination, London: Routledge: 7-8.

Layman, L. 1982. 'Development ideology in Western Australia, 1933-1965'. Historical Studies 20 (79): 234-260.

Lines, W. 1991. Taming the Great South Land: A History of the Conquest of Nature in Australia. Athens and London: University of Georgia Press.

MacNeill, J. 2003. 'Observations on the nature and culture of environmental history'. History and Theory (Theme Issue) 42: 5-43.

McKenna, M. 2002. Looking for Blackfellas' Point: An Australian History of Place. Sydney: UNSW Press.

Melosi, M. 2001. Effluent America: Cities, Industry, Energy, and the Environment. Pittsburgh: University of Pittsburgh Press.

Melosi, M. 2000. The Sanitary City: Urban Infrastructure in America from Colonial Times to the Present. Baltimore: Johns Hopkins University Press.

Melosi, M. 1993. 'The place of the city in environmental history'. Environmental History Review 17 (1): $1-23$.

Melotte, B. 1997. 'Landscape, neighbourhood and accessibility: The contributions of Margaret Feilman to planning and development in Western Australia'. Planning History 19 (2/3): 32-41.

Modjeska, D. 1989. Inner Cities: Australian Women's Memory of Place. Melbourne: Penguin.

Nash, R. 1972. 'American environmental history: A new teaching frontier'. Pacific Historical Review 41: 363-372.

Payne, W. L. 1925. 'First annual report of the Prickly Pear Land Commission'. Brisbane: Queensland Department of Lands. 
Prasad, A. 2003. Against Ecological Nationalism: Verrier Elwin and the Making of an Anti-Modern Tribal Identity. New Delhi: Three Essays.

Price J. 2006. 'Thirteen ways of seeing nature in L.A.'. The Believer (April). Available from: http://www.believermag.com/issues/200604/?read=article_price.

Read, P. 1996. Returning to Nothing: The Meaning of Lost Places. Melbourne: Cambridge University Press.

Read, P. Belonging: Australians, Place and Aboriginal Ownership. Melbourne: Cambridge University Press.

Robin, L.; Connell, D. 'History and the environment'. 2005. In Understanding the Environment: Bridging the Disciplinary Divides by Grafton, R.; Robin, L., et al. Sydney: UNSW Press: 8-22.

Robin, L.; Griffiths, T. 2004. 'Environmental history in Australasia', Environment and History. 10: 439-74.

Rolls, Eric. 1984. They All Ran Wild: The Animals and Plants That Plague Australia. London: Angus \& Robertson.

Rolls, Eric. 1981. A Million Wild Acres. Camberwell, Victoria: Penguin Books.

Rome, A. 2001. The Bulldozer in the Countryside: Suburban Sprawl and the Rise of Environmentalism. Cambridge: Cambridge University Press.

Rome, A. 1994. 'Building on the land: Toward an environmental history of residential development in American cities and suburbs, 1870-1990'. Journal of Urban History 20 (3): 407-434.

Rosen, C.; Tarr, J. 1994. 'The importance of an urban perspective in environmental history'. Journal of Urban History 20 (3): 299-310.

Rosenzweig, R. 1985. Eight Hours for What We Will: Workers \& Leisure in an Industrial City 1870-1920. Cambridge: Cambridge University Press.

Russel, L. 1979. Kwinana 'Third Time Lucky'. Kwinana: Town of Kwinana.

Saberwal, V.; Rangarajan, M., editors. 2003. Battles over Nature, Ecology and Wildlife Series. Delhi: Permanent Black.

Schama, S. 1995. Landscape and Memory. New York: Alfred A Knopf.

Sinclair, P. 2001. The Murray: A River and its People. Melbourne: Melbourne University Press.

Somerville, M. 2004. Wildflowering: The Life and Places of Kathleen Mcarthur. St. Lucia, Qld.: University of Queensland Press.

Star, S.; Griesemer, J. 1989. 'Institutional ecology, 'translations' and boundary objects: Amateurs and professionals in Berkeley's Museum of Vertebrate Zoology, 1907-39'. Social Studies of Science 19: 387-420.

Sundar, N. 1997. Subalterns and Sovereigns: An Anthropological Reader of the History of Bastar, 1854-1996. New Delhi: Oxford University Press.

Tarr, J. 1996. The Search for the Ultimate Sink: Urban Pollution in Historical Perspective. Akron: Ohio, University of Akron Press.

Tyrrell, I. 1999. True Gardens of the Gods: Californian-Australian Environmental Reform, 1860-1930. Berkeley, California: University of California Press: 200-215.

van Sittert, L. 2002. 'Our irrepressible fellow colonist': The biological invasion of Prickly Pear (Opuntia ficus-indica) in the Eastern Cape, c.1890-1910. In South Africa's Environmental History: Cases and Comparisons, edited by Dovers, S.; Edgecombe, R., et al. Athens: Ohio University Press: 139-159.

White, C. 2004a. 'Picnicking, surf-bathing and middle-class morality on the beach in the Eastern suburbs of Sydney, 1811-1912'. Write/Up, Journal of Australian Studies 80: 101-10.

White, R. 2004b. 'From wilderness to hybrid landscapes: The cultural turn in environmental history'. The Historian 66 (3): 557-564.

White, R. 1995. The Organic Machine: The Remaking of the Columbia River. New York: Hill and Wang.

Williams, R. 1984. Keywords: A Vocabulary of Culture and Society. London: Croom Helm.

Williams, R. 1973. The Country and the City. Oxford and New York: Oxford University Press.

Wilson, E. 1998. Consilience: The Unity of Knowledge. New York: Alfred A. Knopf.

Winiwarter, V.; Armiero, M.; van Dam, P.; Dix, A., et al. 2004. 'Environmental history in Europe from 1994 to 2004: Enthusiasm and consolidation'. Environment and History 10 (4): 501-530.

Winiwarter, V. 2005. Convenor 'Natural sciences and history', CISH Sydney. 
Worster, D. 1994. Nature's Economy - A Book of Ecological Ideas. New York: Cambridge University Press. Worster, D. 1990. 'Transformations of the earth: Toward an agroecological perspective in history'. Journal of American History 76: 1087-1106.

Worster, D. 1989. 'Nature and the disorder of history'. Environmental History Review 18: 1-15.

Cite this article as: Brown, Sarah; Dovers, Steve; Frawley, Jodi; Gaynor, Andrea; Goodall, Heather, Karskens, Grace; Mullins, Steve. 2008. 'Can environmental history save the world?' History Australia 5 (1): pp. 3.1 to 3.24. DOI: $10.2104 / \mathrm{ha0} 00003$. 